\title{
Endogenous digitalis-like factors: an overview of the history
}

\section{Vardaman M. Buckalew*}

Medical Center Boulevard, Wake Forest School of Medicine, Winston Salem, NC, USA

Edited by:

Pierrette Gaudreau, Centre

Hospitalier de I'Université de

Montréal Research Center, Canada

Reviewed by:

Ricardo Borges, University of $L a$

Laguna, Spain

Pierrette Gaudreau, Centre

Hospitalier de I'Université de

Montréal Research Center, Canada

Mordecai P. Blaustein, University of

Maryland School of Medicine, USA

*Correspondence:

Vardaman M. Buckalew, Medical Center Boulevard, Wake Forest

School of Medicine, Winston Salem, NC 27157, USA

e-mail:buckalew@wakehealth.edu
The sodium pump is a ubiquitous cell surface enzyme, a $\mathrm{Na}$, K ATPase, which maintains ion gradients between cells and the extracellular fluid (ECF). The extracellular domain of this enzyme contains a highly conserved binding site, a receptor for a plant derived family of compounds, the digitalis glycosides. These compounds inhibit the enzyme and are used in the treatment of congestive heart failure and certain cardiac arrhythmias. The highly conserved nature of this enzyme and its digitalis receptor led to early suggestions that endogenous regulators might exist. Recent examination of this hypothesis emerged from research in two separate areas: the regulation of ECF volume by a natriuretic hormone $(\mathrm{NH})$, and the regulation of peripheral vascular resistance by a circulating inhibitor of vascular $\mathrm{Na}, \mathrm{K}$ ATPase. These two areas merged with the hypothesis that $\mathrm{NH}$ and the vascular $\mathrm{Na}$, K ATPase inhibitor were in fact the same entity, and that it played a causative role in the pathophysiology of certain types of hypertension. The possibility that multiple endogenous digitalis-like factors (EDLFs) exist emerged from efforts to characterize the circulating enzyme inhibitory activity. In this review, the development of this field from its beginnings is traced, the current status of the structure of EDLFs is briefly discussed, and areas for future development are suggested.

Keywords: natriuretic hormone, digitalis-like factor, ouabain, marinobufagenin, bufodienolides, cardenolides

\section{BACKGROUND}

The regulation of salt and water excretion by the kidneys has occupied investigators since at least from the beginning of the 20th century. Highlights of these investigations are documented in early reviews of the subject, notably those by Epstein (1) and Smith (2) in the 1950s. These reviews supported the existence of a receptorintegrator-effector reflex by which changes in some component of the extracellular fluid (ECF) volume ("volume receptors") caused appropriate changes in renal sodium excretion. Both "efferent factors," the numerous hemodynamic, humoral, and neural factors known to directly affect renal sodium excretion, and "afferent factors," the stimuli that activate the efferent factors, were reviewed.

Smith, separating the factors influencing free water excretion from those affecting sodium excretion, considered the mechanism of the latter as being similar to the former. Based on these and other evolutionary considerations, he postulated that the proposed effector for sodium excretion, which he called "Hormone X", was an anti-natriuretic hormone, analogous to antidiuretic hormone, which had evolved to conserve sodium as our primitive ancestors made their "ascent through the brackish waters of the estuary/to the salt poor lakes and ponds" (Strauss) (2). Aldosterone had been identified in the early 1950s, so Smith's Hormone X was clearly proposed as an additional volume sensitive sodium retaining hormone, decreased levels of which would cause natriuresis in response to increased ECF volume.

At the time of Smith's review, it was well established that two factors were preeminent in controlling renal sodium excretion, glomerular filtration rate (GFR), and aldosterone. Thus, Smith's review set the stage for exploration for a "third factor," a term which did not originate with Smith. The earliest investigators to use the term in print, if not the first, were Bricker et al., who were searching for the mechanisms contributing to the progressive increase in the absolute rate of sodium excretion per nephron as the nephron population decreased in chronic renal failure (3). Bricker et al. were the first to recognize that similar mechanisms might contribute to both volume expansion natriuresis and the renal adaptation to chronic renal failure.

\section{THE CONCEPT OF NATRIURETIC HORMONE}

Four years after Smith's review, the mechanism of "volume expansion natriuresis" was addressed in a classic paper by deWardener et al. published in 1961 (4). They showed that natriuresis caused by saline infusion in dogs given large doses of mineralocorticoid was not abolished when GFR was reduced below initial levels by constriction of the aorta above the renal arteries. Furthermore, they showed that blood circulated from volume expanded dogs (donor) to euvolemic dogs (recipient) caused natriuresis in the recipient. Based on these studies, deWardener et al. suggested that volume expansion increased the circulating level of some natriuretic substance, and the concept of "natriuretic hormone" was born.

Three problems quickly emerged after this ground-breaking study was published. First, although the cross circulation studies were careful to control the volume of the recipient dog, the possible effects of blood dilution by the saline infusion in the donor dog were not. In addition, the possibility that the natriuresis in the 
recipient dog might be due to suppression of an anti-natriuretic factor as suggested by Smith had not been definitively eliminated. Each of these issues was addressed in the burst of work in other laboratories that followed the original paper by de Wardener et al. Importantly, these investigators effectively dealt with the dilution issue in a subsequent cross circulation study in which the recipient dog was infused with blood from a reservoir in which blood from both donor and recipient was in equilibrium (5). Other studies addressing the issue of dilution were published by Lichardus et al. and others (6). Studies of the effects of blood dilution on renal sodium excretion subsequently led to exploration of the so called "physical factors" on renal tubular sodium reabsorption by a number of laboratories (7).

In essentially all refinements of the cross circulation studies, the natriuresis in the recipient was much less than that in the donor animal, a finding that was never entirely explained, but some interesting observations were made. For example, response in the recipient was increased by infusing blood from the donor into the aorta just above the renal arteries (8), suggesting a short biologic half-life of the circulating natriuretic factor (9). Also, recipient response was enhanced by preventing the donor from excreting the administered volume load, suggesting some effect of "sustained" volume expansion, an interesting but poorly defined concept that has not been explored further (10).

\section{MECHANISMS OF NATRIURESIS}

The cross circulation studies did not distinguish between the presence of a natriuretic substance versus suppression of an antinatriuretic substance. To make that distinction, a number of laboratories reported natriuretic activity in plasma, urine, and/or kidney tissue of volume expanded animals (11-13), the mechanism of which drew immediate interest. The question was whether the factor caused changes in renal hemodynamics or directly inhibited tubular sodium transport systems. The first studies suggesting the latter were performed by Bricker et al. in which inhibition of p-aminohippurate $(\mathrm{PAH})$ transport by rabbit kidney cortical slices was inhibited by plasma from volume expanded subjects (14). Inhibition of transport in renal tubular epithelium was subsequently shown in isolated tubular cells (15).

Other early studies utilized anuran membranes as models of renal tubular sodium transport. Cort and Lichardus reported inhibition of sodium transport as measured by Ussing's short circuit current (SCC) technique in isolated frog skin by deproteinized, concentrated plasma extracts with very high sodium concentrations (16). In more extensive studies using plasma ultrafiltrates with physiological salt concentrations from volume expanded dogs, Buckalew et al. in 1970 showed similar effects on toad bladder SCC of bufo marinus (17). Ussing and others had demonstrated that the SCC in anuran membrane was due to active sodium transport, and could be inhibited by ouabain. The demonstration that the putative natriuretic hormone inhibited tubular transport and SCC set the stage for investigation of the effect of this factor or factors on $\mathrm{Na}$, K ATPase. The initial attempts to relate natriuretic hormone $(\mathrm{NH})$ to $\mathrm{Na}, \mathrm{K}$ ATPase inhibition were unsuccessful. In the best documented studies, Katz et al. were unable to show inhibition of the enzyme in renal cortical microsomes from volume expanded dogs and rats, or an effect of plasma dialyzates from these animals on renal microsomal $\mathrm{Na}, \mathrm{K}$ ATPase isolated from euvolemic animals (18). However, Gonick et al. subsequently reported that a natriuretic fraction extracted from renal tissue and plasma of volume expanded animals inhibited SCC in frog skin and ouabain sensitive $\mathrm{Na}$, K ATPase isolated from whole rat kidney $(19,20)$.

Studies of the effect of plasma, and extracts of plasma and urine of volume expanded subjects on sodium excretion in assay animals, usually rats, demonstrated two basic patterns that differed primarily in time to peak and duration of effect. The shorter acting pattern showed an immediate onset, a peak effect in 40-60 min, and duration of about $120 \mathrm{~min}(21,22)$. The longer-acting pattern exhibited a delay in onset of 10-60 min, a peak effect in $2-3 \mathrm{~h}$, and duration longer than $3 \mathrm{~h}$ (22). Some initial purification studies indicated that the more rapidly acting factor was found in fractions containing low molecular weight substances, and the longer acting factor appeared in fractions containing high molecular weight substances (23).

\section{NATRIURETIC HORMONE AS INHIBITOR OF Na, K ATPase}

Two major developments in the late 1970s and early 1980s caused a shift in the direction of NH research. The discovery in 1981 of atrial natriuretic factor (ANF) by DeBold et al. (24) and its subsequent characterization as a peptide signaling cascade present in many organs displaced most other lines of investigation with regard to the existence and nature of a NH. Early studies did not show an effect of ANF on Na, K ATPase $(25,26)$; however, subsequent studies revealed a more complex situation (27-29). Nevertheless, it was clear from the early work that ANF and the natriuretic inhibitor of renal epithelial transport systems dependent on Na, K ATPase were two entirely different systems. However, very little further work on the non-ANF NH hypothesis was performed. Instead, the focus shifted to the second major development, namely, that $\mathrm{NH}$ might be an inhibitor of vascular $\mathrm{Na}$, K ATPase that could also be a causative factor in certain types of hypertension.

The suggestion that some types of hypertension, especially those associated with ECF volume expansion, might be due to a circulating inhibitor of vascular $\mathrm{Na}, \mathrm{K}$ ATPase evolved from studies of the phenomenon of potassium-induced vasodilation. Overbeck et al. showed that the dilator response to potassium, but not to other agents, was suppressed in the forelimb of the rat with two kidney, one clip hypertension and the dog with onekidney, one-wrap hypertension (30). Subsequent studies showed that potassium-induced vasodilation was completely blocked by ouabain, leading to the hypothesis that the vasodilation was due to stimulation of vascular smooth muscle Na, K ATPase. According to this hypothesis, stimulation of the electrogenic sodium pump led to hyperpolarization, decreased voltage sensitive influx of calcium, and hence vascular relaxation (31).

Reduced serum potassium produced identical effects in the opposite direction. That is, hypokalemia was associated with vasoconstriction and suppressed Na pump activity, suggesting a cause and effect relationship. As predicted by this paradigm, vascular depolarization was found in several volume expanded hypertension models. Thus, the hypothesis was proposed that vasoconstriction leading to hypertension might be caused by generalized inhibition of vascular $\mathrm{Na}, \mathrm{K}$ ATPase activity (32). In a further 
refinement of the hypothesis in 1976, based on a review of then existing evidence for a humoral factor that slowly increased blood pressure in both animal models and humans with hypertension, Haddy et al. proposed that Na, K ATPase inhibition in vascular tissue, and hence vasoconstriction, might be due to a circulating factor (33). They, in fact, proposed in that review that the postulated circulating inhibitor of $\mathrm{Na}, \mathrm{K}$ ATPase might be "natriuretic hormone." Thus, the two fields of ECF volume regulation and regulation of vascular tone in volume expanded models of hypertension were brought together in the search for a common, explanatory factor (Figure 1).

A unifying explanation for the connection between vascular tone, intracellular calcium concentration, and the sodium pump was proposed by Blaustein in 1977 (34). The model was based on the presence of a $\mathrm{Na}-\mathrm{Ca}$ exchanger located in the plasma membrane, driven by the intracellular-extracellular sodium gradient. According to the hypothesis, supported by kinetic calculations (34), inhibition of the sodium pump by the NH would cause increased vasoconstriction by inhibiting the outward transport of calcium by the $\mathrm{Na}-\mathrm{Ca}$ exchanger.

\section{VOLUME EXPANDED MODELS OF HYPERTENSION}

The NH hypothesis of hypertension raised the question of how volume regulation by a potentially vasoconstrictor $\mathrm{NH}$ occurred in normal versus hypertensive subjects. Volume expanded models of hypertension involved some manipulation that reduced the ability of the kidney to excrete sodium. This approach was based on the concept proposed by Guyton et al. (35) that all hypertension was caused by an abnormal relationship between blood pressure and renal sodium excretion. According to this hypothesis, in normal subjects, renal adaptation to increases and decreases in sodium intake occur without any or with only small changes in systemic blood pressure. However, increased blood pressure is required to maintain ECF volume regulation in the presence of impaired renal sodium excretion through the phenomenon of "pressure diuresis." Guyton postulated the rise in pressure was due to a volume induced increase in cardiac output and the consequent "long term autoregulation" (i.e., vasoconstriction) that ensued. Thus, ECF volume is maintained at the expense of increased peripheral vascular resistance and high blood pressure.

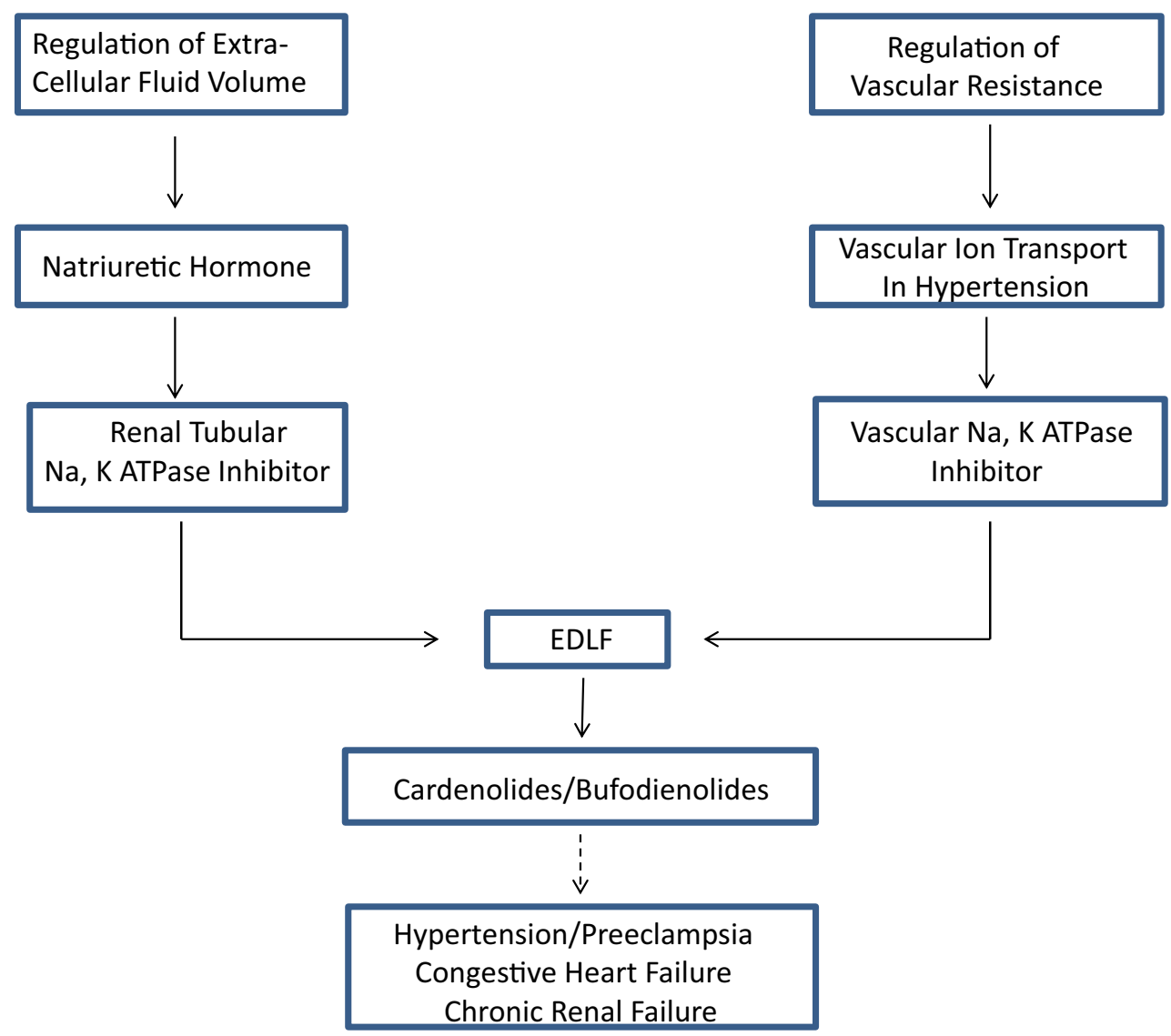

FIGURE 1 |The concept of an endogenous digitalis-like factor (EDLF) that inhibits $\mathrm{Na}$, K ATPase in a manner similar to the cardiac glycosides developed from two lines of investigation (see text), the response of renal sodium excretion to extracellular fluid volume expansion, and the regulation of peripheral vascular resistance in hypertension. Research on the identity of EDLF indicates that mammalian species synthesize two classes of steroids that are either identical to, or analogs of those found in plants (cardenolides) and toads (bufodienolides). Evidence suggests that one or more of these compounds may be involved in the pathophysiology of various hypertensive disorders, chronic renal failure, and congestive heart failure. 
Based on this theory, several investigators proposed a unifying hypothesis incorporating $\mathrm{NH}$ that explained many observations then existing in the literature $(36,37)$. According to this formulation, the defect in renal response to increases in sodium and water intake in hypertensive subjects leads to increases in $\mathrm{NH}$, vascular $\mathrm{Na}$, K ATPase inhibition, vasoconstriction, and increased blood pressure. Volume homeostasis is maintained in the presence of a defect in renal sodium excretion by both the rise in blood pressure through the mechanism of pressure natriuresis, and by the effect of the $\mathrm{NH}$ to inhibit renal tubular sodium reabsorption. The difference between hypertensive and normotensive subjects was, as suggested by deWardener and MacGregor, that the former would be in a "state of continuous correction of a slightly expanded extracellular volume," resulting in a sustained elevation of NH (37). While this concept may have some general validity, the role of EDLF differs in various forms of hypertension (see below).

\section{ENDOGENOUS DIGITALIS-LIKE FACTOR}

Because of the suggestion that $\mathrm{NH}$ might be an inhibitor of $\mathrm{Na}$, $\mathrm{K}$ ATPase, it was subsequently referred to as "ouabain-like" or "digitalis-like." This terminology became more than nomenclature as the field turned to proving the true digitalis-like nature of the circulating factor.

\section{THE CONCEPT OF ENDOGENOUS DRUG-LIKE COMPOUNDS}

The demonstration that the specificity and actions of some drugs were due to drug binding to stereospecific receptors had led to speculation that naturally occurring endogenous compounds existed that bound specifically to these receptors (38). The discovery of endogenous opioids was a direct result of this hypothesis (39). In 1976, Ginzler et al. proposed, as an extension of this concept, that antigen-antibody binding specificity might be analogous to drug-receptor binding specificity (40). That is, an antibody specific for a drug might recognize the same structure as the specific receptor for that drug, and could act as a "surrogate" receptor. This hypothesis had at least two interesting implications. First, antibodies to drugs might recognize endogenous compounds that utilize the same receptor as the drug; and second, antibodies to drugs (or endogenous compounds) might be used to block the effects of those compounds by displacing them from their receptor. The second possibility had already been anticipated by a number of investigators including the demonstration that digoxin antibodies would reverse the clinical manifestations of digoxin intoxication (41).

Based on these concepts, Gruber et al. showed in 1980 that plasma of volume expanded dogs but not euvolemic dogs contained a factor that cross reacted with digoxin antibodies in a specific fashion; i.e., the dose response curve in the digoxin radioimmunoassay (RIA) of the endogenous factor was parallel to that of authentic digoxin (42). Furthermore, plasma extracts containing the digoxin immunoreactive compound inhibited $\mathrm{Na}$, K ATPase, providing further evidence for a true EDLF that had some structural and functional similarity to digoxin. The finding also suggested that digoxin RIAs could be used to study plasma levels of this factor and numerous studies of mammalian "digoxinlike" factor were soon published (43). However, studies using this approach are subject to non-specific cross reactivity of various interfering substances in the digoxin RIA and have led to some confusion $(44,45)$. Interestingly, the first demonstration of an endogenous substance that cross reacts with digoxin antibodies was in newborns, who were suspected of having been poisoned with digoxin (46).

\section{CHARACTERIZATION OF EDLF}

Subsequent to the work briefly described above, numerous attempts have been made to purify and identify the principal factor responsible for the digitalis-like factor demonstrated in volume expanded subjects. According to the initial hypothesis, a truly endogenous, natriuretic, hypertension promoting digitalis-like factor would have the following characteristics. First of all, it would be synthesized endogenously, and secreted under the control of relevant physiological or pathophysiological stimuli. Second, it would inhibit renal and vascular $\mathrm{Na}$, K ATPase in a "ouabain-like" fashion; that is, it would bind to the same receptor and have similar effects on the enzyme as ouabain. Thirdly, its inhibition of renal tubular and vascular $\mathrm{Na}, \mathrm{K}$ ATPase would cause natriuresis and vasoconstriction, respectively. Unfortunately, attempts to identify such a factor have been complicated by the fact that inhibition of the enzyme in various assay systems is a non-specific effect of many diverse compounds (47). As a result, numerous candidate structures have been identified, including steroids, lipids, peptides, and a variety of other novel compounds $(45,48,49)$. A complete review of these reports is beyond the scope of this paper. Rather, we have chosen to focus on a class of compounds that are "digitalis-like" steroids, and which meet the theoretical criteria outlined above, with one exception. They have not been shown unequivocally to be "endogenous" since their synthetic pathway has not been completely elucidated, although preliminary studies suggest they are synthesized in the adrenal gland (50-53).

In 1991, Hamlyn et al. reported purification of a compound indistinguishable from ouabain by mass spectroscopy from 3001 of human plasma (54). Subsequent work seemed to confirm this observation and indicated that mammalian ouabain is present in multiple body fluids and tissues. However, the issue of whether mammalian tissues contain authentic ouabain has remained highly controversial (55-57) despite substantial evidence in support of this finding (58).

Amphibian species have been known for many years to synthesize a number of different steroids called bufodienolides that inhibit Na, K ATPase in a manner similar to the cardenolides (59). Dienolides differ from cardenolides in the structure of the lactone ring, which contains six members and two unsaturated double bonds compared to five members and one double bond in the cardenolides (43). Both cardenolides and dienolides have a $14 \beta$ hydroxyl group and a cis tertiary configuration of the $C / D$ ring junction. Lichstein et al. identified a bufodienolide in toad skin and plasma as resibufogenin (60). They also demonstrated that the concentration of dienolides in toad skin was regulated by the salt content and osmolality of its aquatic environment $(61,62)$.

Bagrov et al. purified a digitalis-like compound from toad venom (63), which they subsequently identified as a previously described bufodienolide marinobufagenin (MBG) (64). Subsequently, purification of a substance from urine of patients after an acute myocardial infarction by high pressure liquid 
chromatography confirmed a structure indistinguishable from authentic MBG (65). Using a polyclonal antibody to toad MBG, they demonstrated increased concentration of a compound recognized by that antibody in plasma of volume expanded dogs (66) and rats (67), and patients with preeclampsia (68). Using antibodies specific for ouabain and MBG, they demonstrated that mammalian plasma contains both ouabain-like and MBG-like compounds (66). Subsequent work has demonstrated that the MBG-like compound meets essentially all the criteria originally postulated for the EDLF-type NH described above $(69,70)$.

Yoshika et al. have shown that MBG immunoreactivity secreted by adrenomedullary derived cells in tissue culture is composed of at least two compounds, MBG and a related compound marinobufotoxin (MBT) (71). MBT was shown to increase blood pressure when administered intraperitoneally to rats (71).

\section{EDLF AND HYPERTENSION}

Using multiple assays for EDLF, numerous studies have attempted to show some correlation between plasma EDLF levels and the blood pressure in human and experimental hypertension, details of which have been previously reviewed and are beyond the scope of this paper $(69,72-80)$ Many of these studies have relied on measurements using RIA technology with antibodies raised against the compound(s) of interest. As noted, these studies are subject to cross reactivity with compounds other than those to which the antibody was raised. Despite these problems, it seems likely that some $\operatorname{EDLF}(\mathrm{s})$ are elevated in some forms of human and experimental hypertension and may play a role in its pathophysiology.

Although most studies of the role of EDLF in hypertension have focused on the circulating factors, it seems likely that endogenous ouabain plays a role in certain types of hypertension through a pathway in the central nervous system (CNS). EDLF has been demonstrated in hypothalamic and pituitary extracts of rats, a compound (or compounds) that crossreacts with a polyclonal anti-ouabain antibody (81). Extensive studies by Huang et al. have shown increases in this compound in the hypothalamus of Dahl salt-sensitive rats (82), spontaneously hypertensive rats (SHR) (83), and normal rats in which blood pressure is increased by an increase in cerebrospinal fluid sodium concentration (84). The critical role of brain EDLF in each of these models was demonstrated by prevention of the rise in blood pressure by CNS administration of a commercially available antigen binding fragment (FAB) of an antidigoxin antibody known to cross react with EDLF (Digibind ${ }^{\circledR}$ ) (see below). A further complexity in the hypertension promoting CNS EDLF system has been demonstrated by studies of central infusion of angiotensin II in rats. This hypertension provoking maneuver causes an increase in circulating endogenous ouabain through activation of a neuronal pathway involving central aldosterone (85).

An integrated role for both endogenous cardenolides and bufodienolides in hypertension in Dahl salt-sensitive rats is suggested by studies showing that release of MBG is controlled by the CNS ouabain pathway discussed above (86). Further studies on the role of CNS pathways in the pathophysiology of hypertension, and in controlling circulating endogenous digitalis-like factors (EDLFs) and blood pressure should be of interest.

\section{REVERSAL OF EDLF EFFECTS BY FUNCTIONAL ANTAGONISTS}

Several functional antagonists of EDLF have been reported to reverse the effects of $\mathrm{Na}, \mathrm{K}$ ATPase inhibition in various clinical and experimental situations, among which are anti-dogoxin and anti-ouabain antiserum, and two steroid compounds, rostafuroxin and resibufagenin, that may be receptor antagonists of one or another component of EDLF.

Digibind $^{\circledR}$ is a purified FAB of a sheep anti-digoxin antibody developed for the treatment of digoxin intoxication that is no longer available commercially. Studies using Digibind ${ }^{\circledR}$ as a probe to assess the possible role of EDLF in hypertensive subjects assume that it will cross react with EDLF, and that in large enough doses will displace EDLF from its receptor, analogous to its effect in digoxin toxicity. A number of studies are compatible with this formulation. Krep et al. showed that Digibind ${ }^{\circledR}$ reduced blood pressure in the DOCA-salt rat model (87). Kaide et al. obtained the same results in a 5/6 reduced renal mass model (88). In the latter study, no effect of Digibind ${ }^{\circledR}$ on blood pressure was observed in sham-operated controls, suggesting that the blood pressure reduction was not due to some non-specific or toxic effect of Digibind ${ }^{\circledR}$ such as an anaphylactoid reaction. Mann et al. had suggested the latter, but their studies were done with commercial preparations other than Digibind ${ }^{\circledR}$ (89). In addition to these in vivo studies, Krep et al. showed that Digibind ${ }^{\circledR}$ reversed the contraction response of isolated aorta to an EDLF isolated from peritoneal dialysis fluid (90). Digibind ${ }^{\circledR}$ has also been reported to reduce blood pressure in several hypertension models when given directly into the CNS $(84,91)$, to block the natriuresis of saline infusion in dogs (66), and to improve neonatal outcomes in fetuses born to patients with preeclampsia (92).

Antibodies against other glycosides have also been shown to lower blood pressure in animal models. Anti-ouabain antibodies had no effect on blood pressure in normal rats (93). However, immunization against ouabain prevented the development of hypertension in Dahl salt-sensitive rats (94), and reduced sodium excretion in normal rats (93). Also, administration of MBG antibodies lowered blood pressure in Dahl salt-sensitive rats (95). These studies suggest that whatever EDLF might be, whether single or multiple compounds, it cross reacts with antibodies against several candidate EDLFs.

In addition to the work with antibodies, two possible receptor antagonists of EDLF have been reported. Rostafuroxin ${ }^{\circledR}$ is a digitoxigenen derivative that selectively displaces ouabain from the $\mathrm{Na}$, K ATPase receptor (96). The compound lowered blood pressure in Milan hypertensive rats (97), but failed to lower blood pressure in clinical trials in essential hypertension in humans (77). Resibufogenin (RBG) is a bufodienolide isolated from toad skin (60) and the traditional Chinese medication Chan Su made from dried toad venom (98). RBG has a structure that only differs from MBG by one oxygen atom on the 5-position of the steroid nucleus (99). Although RBG has "digitalis-like activity" (inhibits in vitro Na, K ATPase activity and ouabain binding) (60), RBG has been shown to lower blood pressure in rat models of preeclampsia and DOCA-salt hypertension (100), both of which have elevated levels of MBG. These data suggest RBG antagonizes at least some effects of MBG, but the exact mechanism has not been elucidated. 
Although similar in structure, different cardenolides and bufodienolides have surprising and unpredictable species and tissue differences in their biological actions (101-103), including antagonism of each other's effects (104-107). The mechanism of the latter phenomenon has been extensively studied by Song et al. (105). They proposed a complex set of models in which $\alpha$ and $\beta$ subunits of $\mathrm{Na}, \mathrm{K}$ ATPase can function as tetraprotomers with varying degrees of aggregation and pump inhibition. This concept may lead to an entirely new method of manipulating sodium pump function that could have clinical implications.

It should also be noted that ACTH induced hypertension in rats can be prevented by making the $\alpha-2 \mathrm{Na}$, K ATPase receptor for cardiac glycosides resistant to those compounds through genetic manipulation (108). This clearly implicates endogenous $\mathrm{Na}, \mathrm{K}$ ATPase inhibitor(s) in the etiology of this type of experimental hypertension.

\section{SUMMARY IN RETROSPECT AND FUTURE DIRECTIONS}

The search for a factor that regulates renal sodium excretion in response to increased blood volume, a NH, stimulated by the experiments of deWardener et al. (4) has produced a huge body of literature, which can no longer be reviewed in a single article. This review, an update of an earlier one (109), emphasizes how the search for a NH converged with studies of the mechanism of increased vascular resistance in hypertension, resulting in the discovery of EDLF(s) (Figure 1). This important discovery has widespread physiologic and pathophysiologic implications and explains, at least in part, the highly conserved nature of the ouabain binding site on membrane $\mathrm{Na}$, K ATPase.

The fact is that, after all the work briefly summarized here, an amazing degree of complexity to a relatively simple if naïve concept has emerged. Regarding the original NH proposal of deWardener et al., no single entity has emerged that fits their hypothesis, and new physiologically relevant natriuretic factors may yet be discovered (9). Atrial natriuretic peptides are clearly volume sensitive natriuretic factors that likely play some role in the renal response to acute volume expansion. ANPs have multiple effects including vasodilation, and one or more of these peptides probably play some role in the pathophysiology of hypertension and congestive heart failure (110). Interactions between ANP and several EDLFs have been demonstrated, which have potentially important physiologic and pathophysiologic implications $(27,111,112)$, and further work in the area can be anticipated.

Ouabain, MBG, and other bufodienolides continue to be investigated as putative physiological regulators of renal and cardiovascular function, but no clear integrating hypothesis has yet emerged. MBG appears to fit the criteria for the circulating factor proposed by the original $\mathrm{NH}$ hypothesis better than ouabain (72), but ouabain is clearly involved in the regulation of sodium excretion by the CNS and further work on this system is anticipated $(9,73)$. The intrarenal mechanism by which bufodienolides cause natriuresis, which involves the recently discovered signaling function of $\mathrm{Na}, \mathrm{K}$ ATPase, should be of ongoing interest (113). The synthetic pathways and tissue(s) origin for the various EDLFs have not yet been completely determined, and high priority should be given to this project (58). If EDLFs play a role in normal physiology and some hypertensive states, as current evidence indicates, interference with their synthesis or antagonism of their effects should provide further insights, and possibly new targets for antihypertensive drugs.

Anti-digoxin antibodies interact with a broad range of EDLFs (114) and have been utilized in both experimental animals and man, with some interesting results $(87,88,115,116)$. Although the commercial preparation used in most of these studies is no longer available, another commercially available preparation of digoxin antibodies (DigiFab ${ }^{\circledR}$ ) has similar if not identical cross reactivity with EDLF (116-118). Finally, the ability of individual cardiotonic steroids (CTS) to interfere with the effects of other CTS has added another layer of complexity and suggests another novel approach to the study of and possible therapy of various conditions in which CTS may be involved (105).

Despite ongoing controversy regarding some of the details (58), the hypothesis that an endogenous regulator(s) of the ouabain binding site on the $\mathrm{Na}, \mathrm{K}$ ATPase enzyme is involved in control of the cardiovascular system has proved to be immensely fertile. Further investigation of these endogenous regulators holds great promise for a better understanding of cardiovascular physiology, the pathophysiology of a diverse set of clinical disorders, including hypertension, preeclampsia, chronic renal failure, congestive heart failure, and cancer (70), and the intricate complexities of the ouabain binding site $(108,119,120)$.

\section{REFERENCES}

1. Epstein FH. Renal excretion of sodium and the concept of volume receptor. Yale J Biol Med (1956) 29(3):282-98.

2. Smith HW. Salt and water volume receptors: an exercise in physiologic apologetics. Am J Med (1957) 23(4):623-52. doi:10.1016/0002-9343(57)90232-2

3. Bricker NS. The control of sodium excretion with normal and reduced nephron populations. The pre-eminence of third factor. Am J Med (1967) 43(3):313-21. doi:10.1016/0002-9343(67)90188-X

4. de Wardener HE, Mills IH, Clappham WF, Hayter CJ. Studies on the efferent mechanism of the sodium diuresis which follows the administration of intravenous saline in the dog. Clin Sci (1961) 21:249-58.

5. Bahlmann J, McDonald SJ, Ventom MG, de Wardener HE. The effect on urinary sodium excretion of blood volume expansion without changing the composition of blood in the dog. Clin Sci (1967) 32(3):403-13.

6. Lichardus B. Early stages of the natriuretic hormone story. Front Endocrinol (Lausanne) (2014) 5:180. doi:10.3389/fendo.2014.00180

7. Martino JA, Earley LE. Demonstraton of a role of physical factors as determinants of the natriuretic response to volume expansion. J Clin Invest (1967) 46(12):1963-78. doi:10.1172/JCI105686

8. Blythe WB, D'Avila D, Gitelman HJ, Welt LG. Further evidence for a humoral natriuretic factor. Circ Res (1971) 28(5):21-31. doi:10.1161/01.RES.28.5.II-21

9. Hamlyn J. Natriuretic hormones, endogenous ouabain, and related sodium transport inhibitors. Front Endocrinol (Lausanne) (2014) 5:199. doi:10.3389/ fendo.2014.00199

10. Sonnenberg H, Veress AT, Pearce JW. A humoral component of the natriuretic mechanism in sustained blood volume expansion. J Clin Invest (1972) 51(10):2631-44. doi:10.1172/JCI107081

11. Kruck F. Influence of humoral factors on renal tubular sodium handling. Nephron (1969) 6(3):205-16. doi:10.1159/000179729

12. Sealey JE, Kirshman JD, Laragh JH. Natriuretic activity in plasma and urine of salt-loaded man and sheep. J Clin Invest (1969) 48(12):2210-24. doi:10.1172/JCI106187

13. Viskoper JR, Czaczkes JW, Schwartz N, Ullmann TD. Natriuretic activity of a substance isolated from human urine during the excretion of a salt load. Comparison of hypertensive and normotensive subjects. Nephron (1971) 8(6):540-8. doi:10.1159/000179959

14. Bricker NS, Klahr S, Purkerson M, Schultze RG, Avioli LV, Birge SJ. In vitro assay for a humoral substance present during volume expansion and uraemia. Nature (1968) 219(5158):1058-9. doi:10.1038/2191058a0 
15. Clarkson EM, Talner LB, de Wardener HE. The effect of plasma from blood volume expanded dogs on sodium, potassium and $\mathrm{PAH}$ transport of renal tubule fragments. Clin Sci (1970) 38(6):617-27.

16. Cort JH, Dousa T, Pliska V, Lichardus B, Safarova J, Vranesic M, et al. Saluretic activity of blood during carotid occlusion in the cat. Am J Physiol (1968) 215(4):921-7.

17. Buckalew VM Jr, Martinez FJ, Green WE. The effect of dialysates and ultrafiltrates of plasma of saline-loaded dogs on toad bladder sodium transport. JClin Invest (1970) 49(5):926-35. doi:10.1172/JCI106312

18. Katz AI, Genant HK. Effect of extracellular volume expansion on renal cortical and medullary Na K ATPase. Pflugers Arch (1971) 330(2):136-48. doi:10.1007/BF00643030

19. Hillyard SD, Lu E, Gonick HC. Further characterization of the natriuretic factor derived from kidney tissue of volume-expanded rats. Effects on shortcircuit current and sodium-potassium-adenosine triphosphatase activity. Circ Res (1976) 38(4):250-5. doi:10.1161/01.RES.38.4.250

20. Gonick HC, Kramer HJ, Paul W, Lu E. Circulating inhibitor of sodiumpotassium-activated adenosine triphosphatase after expansion of extracellular fluid volume in rats. Clin Sci Mol Med (1977) 53(4):329-34.

21. Buckalew VM Jr, Nelson DB. Natriuretic and sodium transport inhibitory activity in plasma of volume-expanded dogs. Kidney Int (1974) 5(1):12-22. doi:10.1038/ki.1974.2

22. Pearce JW, Veress AT, Sonnenberg H. Time course of onset and decay of humoral natriuretic activity in the rat. Can J Physiol Pharmacol (1975) 53(5):734-41. doi:10.1139/y75-102

23. Buckalew VMGKA. Natriuiretic hormone. 2nd ed. In: Epstein M, editor. The Kidney in Liver Disease. New York: Elsevier (1983). p. 479-99.

24. De Bold AJ, Borenstein HB, Veress AT, Sonnenberg H. A rapid and potent natriuretic response to intravenous injection of atrial myocardial extract in rats. Life Sci (1981) 28(1):89-94. doi:10.1016/0024-3205(81)90370-2

25. Sagnella GA, Nolan DA, Shore AC, MacGregor GA. Effects of synthetic atrial natriuretic peptides on sodium-potassium transport in human erythrocytes. Clin Sci (Lond) (1985) 69(2):223-6.

26. Thibault G, Garcia R, Cantin M, Genest J. Atrial natriuretic factor. Characterization and partial purification. Hypertension (1983) 5(2 Pt 2):I75-80. doi:10.1161/01.HYP.5.2_Pt_2.I75

27. Buckalew VM. Atrial peptides modify the effect of marinobufagenin on sodium pumps: implications for blood pressure control. Hypertension (2006) 48(6):1029-30. doi:10.1161/01.HYP.0000248119.54493.18

28. Fedorova OV, Agalakova NI, Morrell CH, Lakatta EG, Bagrov AY. ANP differentially modulates marinobufagenin-induced sodium pump inhibition in kidney and aorta. Hypertension (2006) 48(6):1160-8. doi:10.1161/01.HYP. 0000248129.20524.d0

29. Correa AH, Choi MR, Gironacci M, Valera MS, Fernandez BE. Signaling pathways involved in atrial natriuretic factor and dopamine regulation of renal $\mathrm{Na}$, K ATPase activity. Regul Pept (2007) 138(1):26-31. doi:10.1016/j.regpep.2006. 08.001

30. Overbeck HW. Vascular responses to cations, osmolality, and angiotensin in renal hypertensive dogs. Am J Physiol (1972) 223(6):1358-64

31. Chen WT, Brace RA, Scott JB, Anderson DK, Haddy FJ. The mechanism of the vasodilator action of potassium. Proc Soc Exp Biol Med (1972) 140(3):820-4. doi:10.3181/00379727-140-36560

32. Haddy FJ. Potassium and blood vessels. Life Sci (1975) 16(10):1489-97. doi:10.1016/0024-3205(75)90065-X

33. Haddy FJ, Overbeck HW. The role of humoral agents in volume expanded hypertension. Life Sci (1976) 19(7):935-47. doi:10.1016/00243205(76)90284-8

34. Blaustein MP. Sodium ions, calcium ions, blood pressure regulation, and hypertension: a reassessment and a hypothesis. Am J Physiol (1977) 232(5):C165-73.

35. Guyton AC. Abnormal renal function and autoregulation in essential hypertension. Hypertension (1991) 18(5 Suppl):III49-53. doi:10.1161/01.HYP.18.5_ Suppl.III49

36. Haddy F, Pamnani M, Clough D. The sodium-potassium pump in volume expanded hypertension. Clin Exp Hypertens (1978) 1(3):295-336. doi:10.3109/ 10641967809068611

37. de Wardener HE, MacGregor GA. Dahl's hypothesis that a saluretic substance may be responsible for a sustained rise in arterial pressure: its possible role in essential hypertension. Kidney Int (1980) 18(1):1-9. doi:10.1038/ki.1980.104
38. Gruber KA. Endogenous druglike substances: implications and approaches to their study. Perspect Biol Med (1982) 26(1):51-61. doi:10.1353/pbm.1982.0017

39. Hughes J, Smith TW, Kosterlitz HW, Fothergill LA, Morgan BA, Morris HR. Identification of two related pentapeptides from the brain with potent opiate agonist activity. Nature (1975) 258(5536):577-80. doi:10.1038/258577a0

40. Gintzler AR, Levy A, Spector S. Antibodies as a means of isolating and characterizing biologically active substances: presence of a non-peptide, morphinelike compound in the central nervous system. Proc Natl Acad Sci U S A (1976) 73(6):2132-6. doi:10.1073/pnas.73.6.2132

41. Curd J, Smith TW, Jaton JC, Haber E. The isolation of digoxin-specific antibody and its use in reversing the effects of digoxin. Proc Natl Acad Sci U S A (1971) 68(10):2401-6. doi:10.1073/pnas.68.10.2401

42. Gruber KA, Whitaker JM, Buckalew VM Jr. Endogenous digitalis-like substance in plasma of volume-expanded dogs. Nature (1980) 287(5784):743-5. doi: $10.1038 / 287743 \mathrm{a} 0$

43. Schoner W. Endogenous digitalis-like factors. Prog Drug Res (1993) 41:249-91.

44. Graves SW, Williams GH. Endogenous digitalis-like natriuretic factors. Annu Rev Med (1987) 38:433-44. doi:10.1146/annurev.me.38.020187.002245

45. Goto A, Yamada K, Yagi N, Yoshioka M, Sugimoto T. Physiology and pharmacology of endogenous digitalis-like factors. Pharmacol Rev (1992) 44(3):377-99.

46. Woolfson RG, Poston L, de Wardener HE. Digoxin-like inhibitors of active sodium transport and blood pressure: the current status. Kidney Int (1994) 46(2):297-309. doi:10.1038/ki.1994.275

47. Shlevin HH. Na, K ATPase inhibitors: implications for new drug discovery. Drug Dev Res (1984) 4(3):275-84. doi:10.1002/ddr.430040305

48. Buckalew VM, Haddy FJ. Circulating natriuretic factors in hypertension. In: Laredo J, Brenner BM, editors. Hypertension: Pathophysiology, Diagnosis and Management. New York, NY: Raven Press, Ltd (1990). p. 939-54.

49. Wechter WJ, Benaksas EJ. Natriuretic hormones. Prog Drug Res (1990) 34:231-60.

50. Dmitrieva RI, Bagrov AY, Lalli E, Sassone-Corsi P, Stocco DM, Doris PA. Mammalian bufadienolide is synthesized from cholesterol in the adrenal cortex by a pathway that is independent of cholesterol side-chain cleavage. Hypertension (2000) 36(3):442-8. doi:10.1161/01.HYP.36.3.442

51. Dmitrieva RI, Lalli E, Doris PA. Regulation of adrenocortical cardiotonic steroid production by dopamine and PKA signaling. Front Biosci (2005) 10:2489-95. doi:10.2741/1713

52. Hamlyn JM, Laredo J, Shah JR, Lu ZR, Hamilton BP. 11-hydroxylation in the biosynthesis of endogenous ouabain: multiple implications. Ann N Y Acad Sci (2003) 986:685-93. doi:10.1111/j.1749-6632.2003.tb07283.x

53. Laredo J, Shah JR, Lu ZR, HAMILTON BP, Hamlyn JM. Angiotensin II stimulates secretion of endogenous ouabain from bovine adrenocortical cells via angiotensin type 2 receptors. Hypertension (1997) 29(1):401-7. doi:10.1161/ 01.HYP.29.1.401

54. Hamlyn JM, Blaustein MP, Bova S, DuCharme DW, Harris DW, Mandel F, et al. Identification and characterization of a ouabain-like compound from human plasma. Proc Natl Acad Sci U S A (1991) 88(14):6259-63. doi:10.1073/pnas.88. 21.9907-d

55. Baecher S, Kroiss M, Fassnacht M, Vogeser M. No endogenous ouabain is detectable in human plasma by ultra-sensitive UPLC-MS/MS. Clin Chim Acta (2014) 431C:87-92. doi:10.1016/j.cca.2014.01.038

56. Lewis LK, Yandle TG, Lewis JG, Richards AM, Pidgeon GB, Kaaja RJ, et al. Ouabain is not detectable in human plasma. Hypertension (1994) 24(5):549-55. doi:10.1161/01.HYP.24.5.549

57. Lewis LK, Yandle TG, Hilton PJ, Jensen BP, Begg EJ, Nicholls MG. Endogenous ouabain is not ouabain. Hypertension (2014) 64(4):680-3. doi:10.1161/ HYPERTENSIONAHA.114.03919

58. Blaustein MP. Why isn't endogenous ouabain more widely accepted? Am J Physiol Heart Circ Physiol (2014) 307(5):H635-9. doi:10.1152/ajpheart.00404.2014

59. Flier J, Edwards MW, Daly JW, Myers CW. Widespread occurrence in frogs and toads of skin compounds interacting with the ouabain site of $\mathrm{Na}$, K ATPase. Science (1980) 208(4443):503-5. doi:10.1126/science.6245447

60. Lichtstein D, Kachalsky S, Deutsch J. Identification of a ouabain-like compound in toad skin and plasma as a bufodienolide derivative. Life Sci (1986) 38(14):1261-70. doi:10.1016/0024-3205(86)90418-2

61. Lichtstein D, Gati I, Babila T, Haver E, Katz U. Effect of salt acclimation on digitalis-like compounds in the toad. Biochim Biophys Acta (1991) 1073(1):65-8. doi:10.1016/0304-4165(91)90183-H 
62. Lichtstein D, Gati I, Haver E, Katz U. Digitalis-like compounds in the toad Bufo viridis: tissue and plasma levels and significance in osmotic stress. Life Sci (1992) 51(2):119-28. doi:10.1016/0024-3205(92)90005-A

63. Bagrov AY, Roukoyatkina NI, Fedorova OV, Pinaev AG, Ukhanova MV. Digitalis-like and vasoconstrictor effects of endogenous digoxin-like factor(s) from the venom of Bufo marinus toad. Eur J Pharmacol (1993) 234(23):165-72. doi:10.1016/0014-2999(93)90950-M

64. Bagrov AY, Roukoyatkina NI, Pinaev AG, Dmitrieva RI, Fedorova OV. Effects of two endogenous $\mathrm{Na}$, K ATPase inhibitors, marinobufagenin and ouabain, on isolated rat aorta. Eur J Pharmacol (1995) 274(1-3):151-8. doi:10.1016/00142999(94)00735-P

65. Bagrov AY, Fedorova OV, Dmitrieva RI, Howald WN, Hunter AP, Kuznetsova $\mathrm{EA}$, et al. Characterization of a urinary bufodienolide $\mathrm{Na}, \mathrm{K}$ ATPase inhibitor in patients after acute myocardial infarction. Hypertension (1998) 31(5):1097-103. doi:10.1161/01.HYP.31.5.1097

66. Bagrov AY, Fedorova OV, Dmitrieva RI, French AW, Anderson DE. Plasma marinobufagenin-like and ouabain-like immunoreactivity during saline volume expansion in anesthetized dogs. Cardiovasc Res (1996) 31(2):296-305. doi:10.1016/S0008-6363(95)00208-1

67. Fedorova OV, Doris PA, Bagrov AY. Endogenous marinobufagenin-like factor in acute plasma volume expansion. Clin Exp Hypertens (1998) 20(5-6):581-91. doi:10.3109/10641969809053236

68. Lopatin DA, Ailamazian EK, Dmitrieva RI, Shpen VM, Fedorova OV, Doris PA, et al. Circulating bufodienolide and cardenolide sodium pump inhibitors in preeclampsia. J Hypertens (1999) 17(8):1179-87. doi:10.1097/00004872199917080-00018

69. Bagrov AY, Shapiro JI. Endogenous digitalis: pathophysiologic roles and therapeutic applications. Nat Clin Pract Nephrol (2008) 4(7):378-92. doi:10.1038/ ncpneph0848

70. Bagrov AY, Shapiro JI, Fedorova OV. Endogenous cardiotonic steroids: physiology, pharmacology, and novel therapeutic targets. Pharmacol Rev (2009) 61(1):9-38. doi:10.1124/pr.108.000711

71. Yoshika M, Komiyama Y, Konishi M, Akizawa T, Kobayashi T, Date M, et al. Novel digitalis-like factor, marinobufotoxin, isolated from cultured Y1 cells, and its hypertensive effect in rats. Hypertension (2007) 49(1):209-14. doi:10.1161/01.HYP.0000250433.64202.78

72. Bagrov AY, Fedorova OV. Cardenolide and bufadienolide ligands of the sodium pump. How they work together in $\mathrm{NaCl}$ sensitive hypertension. Front Biosci (2005) 10:2250-6. doi:10.2741/1694

73. Hamlyn JM, Blaustein MP. Salt sensitivity, endogenous ouabain and hypertension. Curr Opin Nephrol Hypertens (2013) 22(1):51-8. doi:10.1097/MNH. 0b013e32835b36ec

74. Hauck C, Frishman WH. Systemic hypertension: the roles of salt, vascular Na, K ATPase and the endogenous glycosides, ouabain and marinobufagenin. Cardiol Rev (2012) 20(3):130-8. doi:10.1097/CRD.0b013e31823c835c

75. Manunta P, Hamlyn JM, Simonini M, Messaggio E, Lanzani C, Bracale M, et al. Endogenous ouabain and the renin-angiotensin-aldosterone system: distinct effects on Na handling and blood pressure in human hypertension. J Hypertens (2011) 29(2):349-56. doi:10.1097/HJH.0b013e32833ea821

76. Schoner W, Scheiner-Bobis G. Endogenous cardiac glycosides: hormones using the sodium pump as signal transducer. Semin Nephrol (2005) 25(5):343-51. doi:10.1016/j.semnephrol.2005.03.010

77. Staessen J, Thijs L, Stolarz-Skrzypek K, Bacchieri A, Barton J, Espositi E, et al. Main results of the ouabain and adducin for specific intervention on sodium in hypertension trial (OASIS-HT): a randomized placebo-controlled phase-2 dose-finding study of rostafuroxin. Trials (2011) 12(1):13. doi:10.1186/17456215-12-13

78. Manunta P, Messaggio E, Ballabeni C, Sciarrone MT, Lanzani C, Ferrandi $\mathrm{M}$, et al. Plasma ouabain-like factor during acute and chronic changes in sodium balance in essential hypertension. Hypertension (2001) 38(2):198-203. doi:10.1161/01.HYP.38.2.198

79. Wang JG, Staessen JA, Messaggio E, Nawrot T, Fagard R, Hamlyn JM, et al. Salt, endogenous ouabain and blood pressure interactions in the general population. J Hypertens (2003) 21 (8):1475-81. doi:10.1097/00004872-20030800000010

80. Tomaschitz A, Piecha G, Ritz E, Meinitzer A, Haas J, Pieske B, et al. Marinobufagenin in essential hypertension and primary aldosteronism: a cardiotonic steroid with clinical and diagnostic implications. Clin Exp Hypertens (2015) 21(2):108-15. doi:10.3109/10641963.2014.913604
81. Ferrandi M, Manunta P, Balzan S, Hamlyn JM, Bianchi G, Ferrari P. Ouabainlike factor quantification in mammalian tissues and plasma: comparison of two independent assays. Hypertension (1997) 30(4):886-96. doi:10.1161/01. HYP.30.4.886

82. Huang BS, Leenen FH. Brain "ouabain” mediates the sympathoexcitatory and hypertensive effects of high sodium intake in Dahl salt-sensitive rats. Circ Res (1994) 74(4):586-95. doi:10.1161/01.RES.74.4.586

83. Huang BS, Leenen FH. Brain 'ouabain', sodium, and arterial baroreflex in spontaneously hypertensive rats. Hypertension (1995) 25(4 Pt 2):814-7. doi:10.1161/01.HYP.25.4.814

84. Huang BS, Harmsen E, Yu H, Leenen FH. Brain ouabain-like activity and the sympathoexcitatory and pressor effects of central sodium in rats. Circ Res (1992) 71(5):1059-66. doi:10.1161/01.RES.71.5.1059

85. Hamlyn JM, Linde CI, Gao J, Huang BS, Golovina VA, Blaustein MP, et al. Neuroendocrine humoral and vascular components in the pressor pathway for brain angiotensin II: a new axis in long term blood pressure control. PLoS One (2014) 9(10):e108916. doi:10.1371/journal.pone.0108916

86. Fedorova OV, Agalakova NI, Talan MI, Lakatta EG, Bagrov AY. Brain ouabain stimulates peripheral marinobufagenin via angiotensin II signalling in $\mathrm{NaCl}$ loaded Dahl-S rats. J Hypertens (2005) 23(8):1515-23. doi:10.1097/01.hjh. $0000174969.79836 .8 \mathrm{~b}$

87. Krep H, Price DA, Soszynski P, Tao QF, Graves SW, Hollenberg NK. Volume sensitive hypertension and the digoxin-like factor. Reversal by a Fab directed against digoxin in DOCA-salt hypertensive rats. Am J Hypertens (1995) 8(9):921-7. doi:10.1016/0895-7061(95)00181-N

88. Kaide J, Ura N, Torii T, Nakagawa M, Takada T, Shimamoto K. Effects of digoxin-specific antibody Fab fragment (Digibind) on blood pressure and renal water-sodium metabolism in 5/6 reduced renal mass hypertensive rats. Am J Hypertens (1999) 12(6):611-9. doi:10.1016/S0895-7061(99)00029-1

89. Mann JF, Miemietz R, Ganten U, Ritz E. Haemodynamic effects of intact digoxin antibody and its Fab fragments in experimental hypertension. J Hypertens (1987) 5(5):543-9. doi:10.1097/00004872-198710000-00006

90. Krep HH, Graves SW, Price DA, Lazarus M, Ensign A, Soszynski PA, et al. Reversal of sodium pump inhibitor induced vascular smooth muscle contraction with digibind. Stoichiometry and its implications. Am J Hypertens (1996) 9(1):39-46. doi:10.1016/0895-7061(95)00260-X

91. Huang BS, Leenen FH. Blockade of brain "ouabain" prevents sympathoexcitatory and pressor responses to high sodium in SHR. Am J Physiol (1996) 271(1 Pt 2):H103-8.

92. Lam GK, Hopoate-Sitake M, Adair CD, Buckalew VM, Johnson DD, Lewis DF, et al. Digoxin antibody fragment, antigen binding (Fab), treatment of preeclampsia in women with endogenous digitalis-like factor: a secondary analysis of the DEEP Trial. Am J Obstet Gynecol (2013) 209(2):.e1-6. doi:10. 1016/j.ajog.2013.04.010

93. Nesher M, Dvela M, Igbokwe VU, Rosen H, Lichtstein D. Physiological roles of endogenous ouabain in normal rats. Am J Physiol Heart Circ Physiol (2009) 297(6):H2026-34. doi:10.1152/ajpheart.00734.2009

94. Gomez-Sanchez EP, Gomez-Sanchez CE, Fort C. Immunization of Dahl SS/jr rats with an ouabain conjugate mitigates hypertension. Am J Hypertens (1994) 7(7 Pt 1):591-6.

95. Fedorova OV, Talan MI, Agalakova NI, Lakatta EG, Bagrov AY. Endogenous ligand of alpha(1) sodium pump, marinobufagenin, is a novel mediator of sodium chloride - dependent hypertension. Circulation (2002) 105(9):1122-7. doi:10.1161/hc0902.104710

96. Quadri L, Bianchi G, Cerri A, Fedrizzi G, Ferrari P, Gobbini M, et al. 17 beta(3-furyl)-5 beta-androstane-3 beta, 14 beta, 17 alpha-triol (PST 2238). A very potent antihypertensive agent with a novel mechanism of action. J Med Chem (1997) 40(11):1561-4. doi:10.1021/jm970162e

97. Ferrari P, Ferrandi M, Valentini G, Bianchi G. Rostafuroxin: an ouabain antagonist that corrects renal and vascular $\mathrm{Na}$, K ATPase alterations in ouabain and adducin-dependent hypertension. Am J Physiol Regul Integr Comp Physiol (2006) 290(3):R529-35. doi:10.1152/ajpregu.00518.2005

98. Xu W, Luo H, Zhang Y, Shan L, Li H, Yang M, et al. Simultaneous determination of five main active bufadienolides of Chan $\mathrm{Su}$ in rat plasma by liquid chromatography tandem mass spectrometry. J Chromatogr B Analyt Technol Biomed Life Sci (2007) 859(2):157-63. doi:10.1016/j.jchromb.2007.09.026

99. Uddin MN, Allen SR, Jones RO, Zawieja DC, Kuehl TJ. Pathogenesis of preeclampsia: marinobufagenin and angiogenic imbalance as biomarkers of the syndrome. Transl Res (2012) 160(2):99-113. doi:10.1016/j.trsl.2012.01.005 
100. Puschett JB, Agunanne E, Uddin MN. Emerging role of the bufadienolides in cardiovascular and kidney diseases. Am J Kidney Dis (2010) 56(2):359-70. doi:10.1053/j.ajkd.2010.01.023

101. Dvela M, Rosen H, Feldmann T, Nesher M, Lichtstein D. Diverse biological responses to different cardiotonic steroids. Pathophysiology (2007) 14(34):159-66. doi:10.1016/j.pathophys.2007.09.011

102. Zulian A, Linde CI, Pulina MV, Baryshnikov SG, Papparella I, Hamlyn JM, et al. Activation of c-SRC underlies the differential effects of ouabain and digoxin on Ca2+ signaling in arterial smooth muscle cells. Am J Physiol Cell Physiol (2013) 304(4):C324-33. doi:10.1152/ajpcell.00337.2012

103. Manunta P, Hamilton J, Rogowski AC, Hamilton BP, Hamlyn JM. Chronic hypertension induced by ouabain but not digoxin in the rat: antihypertensive effect of digoxin and digitoxin. Hypertens Res (2000) 23:S77-85. doi:10.1291/hypres.23.Supplement_S77

104. Feldmann T, Glukmann V, Medvenev E, Shpolansky U, Galili D, Lichtstein $\mathrm{D}$, et al. Role of endosomal Na+-K+-ATPase and cardiac steroids in the regulation of endocytosis. Am J Physiol Cell Physiol (2007) 293(3):C885-96. doi:10.1152/ajpcell.00602.2006

105. Song H, Karashima E, Hamlyn JM, Blaustein MP. Ouabain-digoxin antagonism in rat arteries and neurones. J Physiol (2014) 592(Pt 5):941-69. doi:10.1113/jphysiol.2013.266866

106. Nesher M, Shpolansky U, Viola N, Dvela M, Buzaglo N, Ben-Ami HC, et al. Ouabain attenuates cardiotoxicity induced by other cardiac steroids. Br J Pharmacol (2010) 160(2):346-54. doi:10.1111/j.1476-5381.2010.00701.x

107. Huang BS, Kudlac M, Kumarathasan R, Leenen FHH. Digoxin prevents ouabain and high salt intake-induced hypertension in rats with sinoaortic denervation. Hypertension (1999) 34(4):733-8. doi:10.1161/01.HYP.34.4.733

108. Dostanic-Larson I, Van Huysse JW, Lorenz JN, Lingrel JB. The highly conserved cardiac glycoside binding site of $\mathrm{Na}, \mathrm{K}$-ATPase plays a role in blood pressure regulation. Proc Natl Acad Sci U S A (2005) 102(44):15845-50. doi:10.1073/pnas.0507358102

109. Buckalew VM. Endogenous digitalis-like factors. An historical overview. Front Biosci (2005) 10:2325-34. doi:10.2741/1701

110. Rubattu S, Calvieri C, Pagliaro B, Volpe M. Atrial natriuretic peptide and regulation of vascular function in hypertension and heart failure: implications for novel therapeutic strategies. J Hypertens (2013) 31(6):1061-72. doi:10.1097/HJH.0b013e32835ed5eb

111. Fedorova OV, Kashkin VA, Zakharova IO, Lakatta EG, Bagrov AY. Ageassociated increase in salt sensitivity is accompanied by a shift in the atrial natriuretic peptide modulation of the effect of marinobufagenin on renal and vascular sodium pump. J Hypertens (2012) 30(9):1817-26. doi:10.1097/HJH. 0b013e328356399b

112. Liu LP, Hong L, Yu L, Li HY, Ding DZ, Jin SJ, et al. Ouabain stimulates atrial natriuretic peptide secretion via the endothelin-1/ET(B) receptormediated pathway in beating rabbit atria. Life Sci (2012) 90(19-20):793-8. doi:10.1016/j.lfs.2012.04.008
113. Arnaud-Batista FJ, Costa GT, de Oliveira IMB, Costa PPC, Santos CF, Fonteles $\mathrm{MC}$, et al. Natriuretic effect of bufalin in isolated rat kidneys involves activation of the Na, K ATPase-Src kinase pathway. Am J Physiol Renal Physiol (2012) 302(8):F959-66. doi:10.1152/ajprenal.00130.2011

114. Pullen MA, Brooks DP, Edwards RM. Characterization of the neutralizing activity of digoxin-specific Fab toward ouabain-like steroids. J Pharmacol Exp Ther (2004) 310(1):319-25. doi:10.1124/jpet.104.065250

115. Huang BS, Leenen FH. Sympathoexcitatory and pressor responses to increased brain sodium and ouabain are mediated via brain Ang II. Am J Physiol (1996) 270(1 Pt 2):H275-80.

116. Hopoate-Sitake ML, Adair CD, Mason LA, Torres C, Kipikasa J, Graves SW. Digibind reverses inhibition of cellular $\mathrm{rb}+$ uptake caused by endogenous sodium pump inhibitors present in serum and placenta of women with preeclampsia. Reprod Sci (2011) 18(2):190-9. doi:10.1177/1933719110385133

117. Ishkaraeva-Yakovleva VV, Fedorova OV, Solodovnikova NG, Frolova EV, Bzhelyansky AM, Emelyanov IV, et al. DigiFab interacts with endogenous cardiotonic steroids and reverses preeclampsia-induced Na, K ATPase inhibition. Reprod Sci (2012) 19(12):1260-7. doi:10.1177/1933719112447124

118. Pullen MA, Harpel MR, Danoff TM, Brooks DP. Comparison of non-digitalis binding properties of digoxin-specific Fabs using direct binding methods. J Immunol Methods (2008) 336(2):235-41. doi:10.1016/j.jim.2008.05.005

119. Gable ME, Abdallah SL, Najjar SM, Liu L, Askari A. Digitalis-induced cell signaling by the sodium pump: on the relation of Src to Na, K ATPase. Biochem Biophys Res Commun (2014) 446(4):1151-4. doi:10.1016/j.bbrc.2014. 03.071

120. Lorenz JN, Loreaux EL, Dostanic-Larson I, Lasko V, Schnetzer JR, Paul RJ, et al. ACTH-induced hypertension is dependent on the ouabain-binding site of the \{alpha\}2-Na,K ATPase subunit. Am J Physiol Heart Circ Physiol (2008) 295(1):H273-80. doi:10.1152/ajpheart.00183.2008

Conflict of Interest Statement: The author declares that the research was conducted in the absence of any commercial or financial relationships that could be construed as a potential conflict of interest.

Received: 09 October 2014; accepted: 24 March 2015; published online: 13 April 2015. Citation: Buckalew VM (2015) Endogenous digitalis-like factors: an overview of the history. Front. Endocrinol. 6:49. doi: 10.3389/fendo.2015.00049

This article was submitted to Neuroendocrine Science, a section of the journal Frontiers in Endocrinology.

Copyright $\odot 2015$ Buckalew. This is an open-access article distributed under the terms of the Creative Commons Attribution License (CC BY). The use, distribution or reproduction in other forums is permitted, provided the original author(s) or licensor are credited and that the original publication in this journal is cited, in accordance with accepted academic practice. No use, distribution or reproduction is permitted which does not comply with these terms. 